\title{
Simian Immunodeficiency Virus Infection Alters Chemokine Networks in Lung Tissues of Cynomolgus Macaques
}

\section{Association with Pneumocystis carinii Infection}

Shulin Qin, ${ }^{*}$ Beth A. Fallert Junecko, ${ }^{*}$

Anita M. Trichel, ${ }^{\dagger}$ Patrick M. Tarwater, ${ }^{\ddagger}$ Michael A. Murphey-Corb, ${ }^{\dagger}$ Denise E. Kirschner, ${ }^{\S}$ and Todd A. Reinhart ${ }^{\star}$

\begin{abstract}
From the Department of Infectious Diseases and Microbiology, Graduate School of Public Health, and the Department of Molecular Genetics and Biochemistry, ${ }^{\dagger}$ School of Medicine, University of Pittsburgh, Pittsburgh, Pennsylvania; the Department of Biomedical Sciences, ${ }^{\ddagger}$ Paul L. Foster School of Medicine, Texas Tech University Health Sciences Center, El Paso, Texas; and the Department of Microbiology and Immunology, University of Michigan, Ann Arbor, Michigan
\end{abstract}

Infection by HIV-1 frequently leads to pulmonary complications, including alterations to local immune environments. To better understand these alterations, we have examined in detail the patterns and levels of expression of chemokine, cytokine, and chemokine receptor mRNAs in lung tissues from 16 uninfected or simian immunodeficiency virus (SIV)/DeltaB670 infected cynomolgus macaques at different stages of infection. Among the most up-regulated immune genes were interferon (IFN)- $\gamma$, IFN- $\gamma$-inducible CXCR3 ligands, and CCR5 ligands, as well as the cognate chemokine receptors. These changes were greatest in animals with clear Pneumocystis carinii coinfection. Immunohistochemistry and in situ hybridization revealed monocytes/macrophages to be the predominant type of cell infiltrating into lung tissues and serving as the major cellular source of chemokines. To explore the causes of chemokine alterations, we treated macaque lung cells with IFN- $\gamma$, lipopolysaccharide, Poly(I:C), and P. carinii in vitro, and results revealed that these stimuli can induce the expression of CXCR3 ligand and/or CCR5 ligand mRNAs. Taken together, these studies provide a comprehensive definition of the chemokine networks available to modulate cellular recruitment to lung tissues during SIV infection and implicate both cytokines
(IFN- $\gamma$ ) and pathogens (SIV and P. carinii) as contributors to increased expression of pro-inflammatory chemokines. (Am J Patbol 2010, 177:1274-1285; DOI: 10.2353/ajpatb.2010.091288)

Pulmonary diseases are frequent complications of HIV-1 infection, affecting $75 \%$ to $85 \%$ of patients with AIDS. ${ }^{1}$ In addition, Pneumocystis carinii (now called Pneumocystis jirovecii in humans) pneumonia (PCP) is one of most frequent pulmonary opportunistic infections in HIV-1 infected individuals. However, little is known about the mechanisms leading to changes in pulmonary immune function and how these changes ultimately contribute to pathogenesis. Identifying alterations of overall immune function and the local mediators of these changes in the lungs during HIV-1 infection and AIDS will be useful for understanding and treating HIV-1-associated pulmonary complications.

Chemokines are soluble immune factors that recruit cells bearing appropriate receptors into local environments as part of homeostatic immune cell trafficking and inflammatory reactions. There are approximately 50 known chemokines and 18 chemokine receptors. ${ }^{2}$ Chemokines play an important role in the control of infectious agents by recruiting effector cells to local inflammatory sites of infection and by serving directly as antimicrobial peptides. ${ }^{3}$ During HIV-1 infection, chemokines and their receptors have important roles in virus/host interactions because a subset of chemokine receptors act as viral entry co-receptors ${ }^{4}$ and natural and modified ligands for

Supported by National Institutes of Health grants RO1 HL072682 (D.E.K.) and RO1 Al060422 (T.A.R.).

Accepted for publication April 28, 2010.

Address reprint requests to Todd A. Reinhart, ScD, Professor, Department of Infectious Diseases and Microbiology, Graduate School of Public Health, University of Pittsburgh, 606 Parran Hall, 130 DeSoto St, Pittsburgh, PA 15261. E-mail: reinhar@pitt.edu. 
these receptors can inhibit viral infection..$^{5,6}$ Chemokines mediate immunity and host defense, but when produced in inappropriate amounts or in inappropriate contexts they may also contribute to inflammation-associated pathology. Either the absence or excess of specific chemokines might affect immune responses and thereby affect susceptibility to infection or subsequent disease progression. ${ }^{7}$ Because inflammatory chemokines play both beneficial and harmful roles in infectious diseases, there is a need for further study of the interactions between microbes, infected host cells, and other cells of the immune system to determine the relations between direct and indirect effects of the microbes on changing local chemokine expression and inflammation.

Simian immunodeficiency virus (SIV) infection can lead to immune dysfunction in multiple species of nonhuman primates, and macaques with AIDS often are infected with opportunistic pathogens such as $P$. carinii. Therefore, we hypothesized that SIV and/or $P$. carinii infections in nonhuman primate model systems might broadly alter chemokine networks in lung tissues, and thereby contribute to SIV-associated pulmonary pathogenesis. To address this issue, we used the SIV-infected cynomolgus macaque (Macaca fascicularis) model to investigate the relations between systemic SIV infection, local SIV and/or $P$. carinii infections, and changes in chemokine, chemokine receptor, and cytokine expression. We present here a comprehensive analysis of the expression of chemokines and their receptors in lung tissues during SIV infection by using real-time RT-PCR and in situ hybridization (ISH). We also used simultaneous detection strategies to define infiltrating cell types and cellular sources of che- mokines in lung tissues. In addition, we measured the expression of Toll-like receptors (TLRs) 1 to 10 in macaque lung tissues to determine the overall pathogensensing capabilities of this large mucosal organ. Altogether, our findings identify associations between local levels of SIV and P. carinii, and increased expression of inflammatory chemokines.

\section{Materials and Methods}

\section{Animals and Tissue Processing}

These studies were performed under the approval and guidance of the University of Pittsburgh Institutional Animal Care and Use Committee. The University of Pittsburgh facilities are accredited by the American Association for Accreditation of Laboratory Animal Care. The 16 adult cynomolgus macaques ( $M$. fascicularis) used in this study were negative for SIV, simian retrovirus, and simian T-lymphotropic virus type 3-III at the initiation of the study. These macaques were inoculated intrarectally with a characterized stock of the pathogenic SIV/DeltaB670 isolate ${ }^{8}$ and details regarding their clinicovirological states are described in Table 1. The animals' clinical conditions were observed a minimum of twice daily for changes in behavior, posture and activity, food/water consumption, stool and urine output, and evidence of pain/discomfort or neurological signs. Animals exhibiting signs such as weight loss, anorexia, wasting, diarrhea, and pneumonia were treated at the direction of the facility veterinarian with appropriate antibiotics, nutritional supplementation,

Table 1. Study Animals and Clinicovirologic States

\begin{tabular}{|c|c|c|c|c|c|c|}
\hline Animal & Stage of infection & Virus* & $\begin{array}{c}\text { Wk } \\
\text { postinfection }\end{array}$ & $\begin{array}{c}\text { Viral load in } \\
\text { plasma }^{\dagger} \\
\text { (copies } / \mathrm{ml})\end{array}$ & $\begin{array}{l}\text { Lung } \\
\text { tissue viral } \\
\text { load }^{\mp}\end{array}$ & Clinical findings \\
\hline M6202 & Uninfected & None & NA & $N D^{\S}$ & $<0.01$ & Normal \\
\hline M7102 & Uninfected & None & NA & ND & $<0.01$ & Normal \\
\hline M13402 & Uninfected & None & NA & ND & $<0.01$ & Normal \\
\hline M13502 & Uninfected & None & NA & ND & $<0.01$ & Normal \\
\hline M5702 & Exposed/uninfected & SIV/DeltaB670 & 2 & ND & $<0.01$ & Normal \\
\hline M7402ๆ & Exposed/uninfected & SIV/DeltaB670 & 2 & ND & $<0.01$ & Normal \\
\hline M6002 & Acute & SIV/DeltaB670 & 2 & $2,600,000$ & 8.36 & Normal \\
\hline M7902 & Acute & SIV/DeltaB670 & 2 & $3,100,000$ & 4.53 & Normal \\
\hline M13002 & Clinical latency & SIV/DeltaB670 & 8 & 180 & 0.08 & Normal \\
\hline M13102 & Clinical latency & SIV/DeltaB670 & 8 & $3,600,000$ & 0.20 & Normal \\
\hline M5802 & AIDS & SIV/DeltaB670 & 49 & $1,950,000$ & 0.10 & $\begin{array}{l}\text { Weight loss, CD4 }{ }^{+} \text {T-lymphocyte } \\
\text { decrease }\end{array}$ \\
\hline M5902 & AIDS & SIV/DeltaB670 & 14 & $1,750,000$ & 0.90 & $\begin{array}{l}\text { Weight loss, CD4+ T-lymphocyte } \\
\text { decrease, lymphoma }\end{array}$ \\
\hline M7002 & AIDS & SIV/DeltaB670 & 48 & 640,000 & 0.02 & $\begin{array}{l}\text { Weight loss, CD4 }{ }^{+} \text {T-lymphocyte } \\
\text { decrease, watery diarrhea }\end{array}$ \\
\hline M12402 & AIDS & SIV/DeltaB670 & 42 & 4100 & 0.30 & $\begin{array}{l}\text { Weight loss, CD4 }{ }^{+} \text {T-lymphocyte } \\
\text { decrease, PCP }\end{array}$ \\
\hline M12602 & AIDS & SIV/DeltaB670 & 39 & 140,000 & 0.73 & $\begin{array}{l}\text { Weight loss, } \mathrm{CD}^{+}{ }^{+} \text {T-lymphocyte } \\
\text { decrease, PCP }\end{array}$ \\
\hline M12802 & AIDS & SIV/DeltaB670 & 37 & 286,000 & 1.33 & $\begin{array}{l}\text { Weight loss, CD4 }{ }^{+} \text {T-lymphocyte } \\
\text { decrease, PCP }\end{array}$ \\
\hline
\end{tabular}

*Intrarectal infection.

${ }^{\dagger}$ Real-time RT-PCR was used to determine plasma viral loads at necropsy.

†Real-time RT-PCR was used to determine tissue-associated viral loads, with normalization to the copy numbers of $\beta 2 m$ mRNA ( $\times 1000$ )

$\S \mathrm{ND}$, not determined.

"SIV was undetectable in plasma and lung. 
and supportive care, including analgesics to alleviate pain. Animals were sacrificed via sedation with ketamine (10 to $20 \mathrm{mg} / \mathrm{kg}$ ) followed by an intravenous dose of sodium pentobarbital (25 $\mathrm{mg} / \mathrm{kg}$ ), in compliance with the 2007 American Veterinary Medical Association guidelines. Transcardial perfusion was performed with saline to minimize blood contamination of tissues.

Tissues from all major organ systems were obtained at necropsy, and either snap-frozen or fixed by immersion in fresh 4\% paraformaldehyde/PBS and processed as described. ${ }^{9}$ Total lung cells were prepared by mincing lung tissues from uninfected macaques in RPMI-1640 medium (with L-glutamine, penicillin, streptomycin, and 10\% fetal calf serum) containing $0.7 \mathrm{mg} / \mathrm{ml}$ collagenase $A$ and 50 $\mu \mathrm{g} / \mathrm{ml}$ DNase and then incubated at $37^{\circ} \mathrm{C}$ in $5 \% \mathrm{CO}_{2}$ for 1 hour. The resulting mixture was run through a 100micron strainer, and the clarified cell suspension was lysed in an ammonium chloride red blood cell lysing solution followed by washing twice in $1 \times$ PBS. Cells were frozen overnight at $-85^{\circ} \mathrm{C}$ at $1 \times 10^{7}$ cells per $\mathrm{ml}$ in $10 \%$ dimethyl sulfoxide/90\% fetal calf serum and then stored over liquid nitrogen. A test thaw of cells from four different macaques indicated that the viabilities of these cells after long-term storage (>3 years) were $71.3 \%(+/-5.9 \%$ [SD]). Plasma and tissue viral RNA loads were measured by real-time RT-PCR as described. ${ }^{10,11}$

\section{ISH and Immunohistochemistry}

ISHs for cellular and pathogen (SIV and $P$. carinii) RNAs were performed as described. 9,12,13 Autoradiographic exposure times, following ISH with antisense and control sense ${ }^{35}$ S-labeled riboprobes specific for SIV, $P$. carinii, interferon (IFN)- $\gamma$, and chemokine RNAs were 7 to 10 days.

Immunohistochemistry ( $\mathrm{IHC}$ ) was performed with a rat anti-CD3 monoclonal antibody (clone CD3-12, Novocastra, Newcastle upon Tyne, UK) or murine monoclonal antibodies specific for CD68 (clone KP1, Dako, Carpenteria, CA), CD20 (clone L26, Dako), CD209/DC-SIGN (clone DCN46, BD Pharmingen, San Diego, CA), CD183/ CXCR3 (clone, 1C6, BD Pharmingen), or keratins (AE1/ AE3/PCK26, Ventana Medical Systems Inc., Tucson, AZ). $\mathrm{IHC}$ was performed on cryosections that were postfixed in $4 \%$ paraformaldehyde/PBS, washed in absolute ethanol, and microwaved in $0.01 \mathrm{M}$ sodium citrate $(\mathrm{pH} 6.0)$ for a total of 10 minutes in 2-minute increments. Tissue sections were incubated with primary antibodies for 1 hour at room temperature and detected by using the SuperPicTure Kit (Zymed Laboratories Inc., South San Francisco, $\mathrm{CA}$ ), according to the manufacturer's recommendations. Counterstaining was performed with hematoxylin (Fisher Chemicals, Fairlawn, NJ). For combined ISH/IHC, tissue sections were subjected to $\mathrm{IHC}$ immediately following $\mathrm{ISH}$, with subsequent autoradiographic exposure times of 5 to 10 days.

\section{Real-Time RT-PCR}

RNA extraction, template preparation, and real-time RTPCR were performed by using a two-step protocol as described, ${ }^{13,14}$ with RT-negative controls always performed in parallel. PCR amplification was performed by using $2.5 \mu \mathrm{l}$ of each cDNA in TaqMan Universal PCR Master Mix with TaqMan primer/probe combinations in a total volume of $25 \mu \mathrm{l}$. Primer and probe sequences for real-time RT-PCR were either purchased as gene-specific sets (Applied Biosystems, Foster City, CA) or designed by using the Primer Express Software package (Applied Biosystems). The assays we designed were for the following mRNAs: CCL3, CXCL10, CXCL11, CXCL13, CCL23, XCL1, CCR5, and CCR9. Interleukin (IL)-10 primer and probe sequences were identical to those previously described. ${ }^{15}$ The assays were run by using an ABI PRISM 7000 Sequence Detection System (Applied Biosystems). Gene expression was normalized to the endogenous control mRNA, $\beta$-glucuronidase. The relative expression levels of cellular mRNAs were calculated by using the comparative cycle threshold (Ct) method $^{10,16}$ with an RNA sample from an uninfected macaque serving as the calibrator.

\section{Culture, Treatment, and Analysis of Macaque Lung Cells}

Cryopreserved macaque lung cells were thawed, counted, and plated ( $5 \times 10^{5}$ viable cells $\left./ \mathrm{ml}\right)$ in complete RPMI-1640 culture medium containing 10\% fetal bovine serum. Cells were treated with IFN- $\gamma$ (R\&D Systems, Minneapolis, MN; $20 \mathrm{ng} / \mathrm{ml}$ ), lipopolysaccharide (LPS; InvivoGen; $1 \mu \mathrm{g} / \mathrm{ml}$ ), Poly(l:C) (InvivoGen, San Diego, CA; 25 $\mu \mathrm{g} / \mathrm{ml}$ ), or $5 \times 10^{5} \mathrm{P}$. carinii cysts (kindly provided by Dr. Terry Wright, University of Rochester). At 0, 6, and 24 hours of culture $\left(37^{\circ} \mathrm{C}, 5 \% \mathrm{CO}_{2}\right)$, supernatants and cells were harvested and stored at $-80^{\circ} \mathrm{C}$ until enzymelinked immunosorbent assay (ELISA) and real-time RTPCR analyses were performed, respectively. The levels of CXCL10 in supernatants of cultured lung cells were measured by ELISA (R\&D Systems) according to the manufacturer's recommendations.

\section{Statistical Analyses}

All statistical analyses were performed with the Minitab software package (State College, PA). Real-time RT-PCR data were analyzed by using the two-sample $t$-test, paired $t$-test, Mann-Whitney nonparametric test, and Pearson's correlation analyses. A $P$ value $<0.05$ was considered significant.

\section{Results}

\section{Study Animals}

To understand better the immunological and virologic events in lung tissues during SIV infection, we examined tissues from four uninfected and 12 SIV-infected adult cynomolgus macaques (Table 1). Infected animals were inoculated intrarectally with the pathogenic SIV/DeltaB670 isolate and sacrificed at different times after infection. 
Four animals were sacrificed 2 weeks postinfection $(\mathrm{PI})$, with two of these four animals subsequently determined to be exposed to SIV but uninfected, as revealed by plasma and tissue viral load analyses. In the remaining macaques, SIV plasma viral loads ranged from $1.8 \times 10^{2}$ to $3.6 \times 10^{6}$ copies $/ \mathrm{ml}$ (Table 1 ). Two macaques that we defined as being in a chronic state of infection were sacrificed at 8 weeks postinfection. The remaining six macaques were maintained until they progressed to AIDS at 14 to 49 weeks postinfection. Among animals with AIDS, in addition to weight loss and $\mathrm{CD} 4^{+} \mathrm{T}$-lymphocyte loss, one animal suffered from lymphoma, one animal had watery diarrhea, and three animals harbored widespread infection with $P$. carinii in the lungs.

\section{SIV Infection Alters Chemokine and Chemokine Receptor Expression Profiles in Macaque Lung Tissues}

To measure the effects of SIV infection on the chemokine expression profiles in lung tissues, we performed realtime RT-PCR for 18 different chemokine mRNAs. These 18 targets were chosen based on standard RT-PCR analyses of 38 chemokine mRNAs (data not shown) that defined groups of chemokines that increased or decreased in expression, or remained unchanged. Ten of these chemokine mRNAs were increased in expression following SIV infection (Table 2). The chemokines that were up-regulated were predominantly inflammatory che-

Table 2. Measurement of Chemokine and Cytokine mRNA Expression Levels in Lung by Real-time RT-PCR

\begin{tabular}{|c|c|c|c|c|c|c|c|c|c|}
\hline & \multirow[b]{2}{*}{ mRNA } & \multirow[b]{2}{*}{$\begin{array}{l}\text { Uninfected } \\
\qquad(n=6)\end{array}$} & \multirow[b]{2}{*}{$\begin{array}{l}\text { SIV-infected } \\
\quad(n=10)\end{array}$} & \multirow[b]{2}{*}{$\begin{array}{c}\text { AIDS } \\
(n=3)\end{array}$} & \multirow[b]{2}{*}{$\begin{array}{c}\text { AIDS + PCP } \\
(n=3)\end{array}$} & \multicolumn{2}{|c|}{ Fold-change } & \multicolumn{2}{|c|}{$P^{\star}$} \\
\hline & & & & & & $\begin{array}{c}\text { SIV } \\
\text { versus } \\
\text { UI }\end{array}$ & $\begin{array}{c}\text { AIDS } \\
\text { versus } \\
\text { UI }\end{array}$ & $\begin{array}{c}\text { SIV } \\
\text { versus } \\
\text { UI }\end{array}$ & $\begin{array}{c}\text { AIDS } \\
\text { versus } \\
\text { UI }\end{array}$ \\
\hline \multirow{10}{*}{$\begin{array}{l}\text { Chemokines }^{\dagger} \\
\text { (Increased) }\end{array}$} & CXCL9/MIG & $1.2^{\ddagger}$ & 10.8 & 13.9 & 7.2 & 9.4 & 9.2 & 0.010 & 0.032 \\
\hline & CXCL10/IP10 & 1.9 & 13.4 & 12.6 & 11.9 & 7.1 & 6.5 & $<0.001$ & 0.006 \\
\hline & CXCL11/I-TAC & 1.1 & 5.1 & 5.5 & 5.2 & 4.7 & 4.9 & $<0.001$ & 0.005 \\
\hline & CCL2/MCP1 & 1.9 & 7.0 & 4.5 & 10.3 & 3.7 & 3.9 & 0.041 & 0.036 \\
\hline & CCL3/MIP-1 $\alpha$ & 2.6 & 8.7 & 7.2 & 16.0 & 3.3 & 4.4 & 0.016 & 0.012 \\
\hline & CCL4/MIP-1 $\beta$ & 1.2 & 2.5 & 2.1 & 3.9 & 2.1 & 2.6 & 0.045 & 0.030 \\
\hline & CCL18/PARC & 0.7 & 2.2 & 3.1 & 1.3 & 3.3 & 3.4 & 0.022 & NS \\
\hline & CCL19/MIP-3 $\beta$ & 0.9 & 4.9 & 5.7 & 6.9 & 5.4 & 7.1 & 0.009 & 0.014 \\
\hline & CCL20/MIP-3 $\alpha$ & 1.7 & 9.2 & 11.0 & 13.3 & 5.3 & 7.0 & 0.043 & NS \\
\hline & CXCL13/BCA-1 & 0.8 & 3.4 & 6.8 & 0.9 & 4.1 & 4.7 & NS & NS \\
\hline \multirow{4}{*}{$\begin{array}{l}\text { Chemokines } \\
\text { (Decreased) }\end{array}$} & CCL25/TECK & 1.1 & 0.5 & 0.7 & 0.1 & 0.4 & 0.4 & 0.035 & 0.026 \\
\hline & CCL21/6Ckine & 0.9 & 0.3 & 0.3 & 0.1 & 0.4 & 0.2 & NS & 0.049 \\
\hline & CCL17/TARC & 1.9 & 0.8 & 1.7 & 0.1 & 0.4 & 0.5 & NS & NS \\
\hline & CXCL12/SDF- $1 \alpha$ & 0.8 & 0.5 & 0.4 & 0.2 & 0.6 & 0.4 & NS & NS \\
\hline Chemokines & CX3CL1/Fractalkine & 0.9 & 1.2 & 1.9 & 0.1 & 1.3 & 1.1 & NS & NS \\
\hline \multirow[t]{3}{*}{ (No change) } & CCL23/MPIF-1 & 1.3 & 1.3 & 1.4 & 1.5 & 1.0 & 1.1 & NS & NS \\
\hline & CCL5/RANTES & 0.6 & 0.8 & 1.1 & 0.4 & 1.4 & 1.4 & NS & NS \\
\hline & XCL1/Lymphotactin & 2.0 & 2.9 & 3.2 & 1.1 & 1.5 & 1.1 & NS & NS \\
\hline \multirow[t]{5}{*}{ Cytokines } & IFN- $\gamma$ & 0.8 & 5.4 & 2.9 & 5.4 & 6.8 & 5.2 & 0.004 & 0.010 \\
\hline & IFN- $\alpha 2$ & 1.6 & 0.9 & 0.6 & 0.1 & 0.6 & 0.2 & NS & NS \\
\hline & IFN- $\beta 1$ & 1.3 & 0.9 & 0.7 & 0.2 & 0.6 & 0.3 & NS & NS \\
\hline & TNF- $\alpha$ & 5.3 & 2.3 & 3.1 & 0.5 & 0.4 & 0.3 & NS & NS \\
\hline & IL-10 & 1.8 & 8.0 & 8.2 & 12.3 & 4.4 & 5.6 & 0.031 & 0.047 \\
\hline Chemokine & CCR1 & 1.0 & 1.7 & 1.6 & 2.3 & 1.8 & 2.1 & 0.044 & NS \\
\hline \multirow[t]{11}{*}{ receptors $\$$} & CCR3 & 7.2 & 5.6 & 12.0 & 1.5 & 0.8 & 1.0 & NS & NS \\
\hline & CCR4 & 1.1 & 1.0 & 1.1 & 0.5 & 0.9 & 0.7 & NS & NS \\
\hline & CCR5 & 0.7 & 1.7 & 0.6 & 1.4 & 1.4 & 1.5 & 0.006 & 0.046 \\
\hline & CCR6 & 0.7 & 0.7 & 0.6 & 0.6 & 1.0 & 0.9 & NS & NS \\
\hline & CCR7 & 0.6 & 0.8 & 0.9 & 0.3 & 1.3 & 1.0 & NS & NS \\
\hline & CCR9 & 1.4 & 2.1 & 2.2 & 0.9 & 1.5 & 1.1 & NS & NS \\
\hline & CCR11 & 1.0 & 1.2 & 1.0 & 0.4 & 1.2 & 0.7 & NS & NS \\
\hline & CXCR3 & 1.4 & 5.6 & 4.6 & 2.1 & 3.9 & 2.4 & 0.011 & 0.001 \\
\hline & CXCR4 & 1.1 & 0.7 & 0.7 & 0.1 & 0.7 & 0.4 & NS & NS \\
\hline & CXCR5 & 0.5 & 0.7 & 0.9 & 0.3 & 1.5 & 1.3 & NS & NS \\
\hline & CX3CR1 & 0.8 & 1.3 & 2.0 & 0.1 & 1.8 & 1.4 & NS & NS \\
\hline $\begin{array}{l}\text { Toll-like } \\
\text { receptor }\end{array}$ & TLR3 & 1.0 & 4.9 & 4.6 & 1.2 & 5.1 & 3.1 & $0.013^{\pi}$ & $0.046^{\text {ๆ }}$ \\
\hline
\end{tabular}

\footnotetext{
UI, uninfected.
}

*Student's $t$-tests were performed for all comparisons, except as noted.

${ }^{+}$Chemokines were grouped as increase, decrease, or unchanged based on a group fold-change >2 (SIV versus UI and/or AIDS versus UI) and/or $P$ value $<0.05$.

${ }^{\ddagger}$ Arithmetical mean of the fold-change in mRNA expression relative to an uninfected calibrator animal.

§CCR2, CCR8, CCR10, CXCR1, CXCR2, and XCR1 were not detectable in any RNA samples (Ct > 45).

"Mann-Whitney nonparametric test. 
mokines including the IFN-inducible CXCR3 ligands (CXCL9, CXCL10, and CXCL11), CCL2, and the CCR5 ligands CCL3 and CCL4. CCL19 was also increased in expression, which also could be interpreted as an inflammatory response given that it is one of the most highly up-regulated genes on activation of dendritic cells (DCs). ${ }^{17,18}$ Chemokines CCL18, CCL20, and CXCL13 are more homeostatic in function, with CCL18 constitutively expressed by lung macrophages, ${ }^{19}$ and $\mathrm{CCL} 2 \mathrm{O}^{20}$ and $\mathrm{CXCL} 13^{21}$ expressed in secondary lymphoid tissues. Among the animals with AIDS, three also had PCP, and these animals exhibited a number of differences from animals with AIDS alone, including higher levels of induction of CCL2 and CCL3, and lack of induction of CXCL13 (Table 2).

Decreased expression was observed for four of the 18 chemokines examined, including CCL25, CCL21, CCL17, and CXCL12, although only the changes with CCL25 and CCL21 were statistically significant. CCL25 is homeostatically expressed predominantly in small intestine and thymus, ${ }^{22,23}$ whereas CCL21 is homeostatically expressed in secondary lymphoid tissues ${ }^{24}$ and by peripheral tissue lymphatic endothelial cells. ${ }^{24,25}$ Although expression of CCL25 in lung and then its loss were unexpected, we have previously shown expression and loss of CCL25 mRNA in lymphoid tissues. ${ }^{26}$ The animals with AIDS and PCP showed more potent down-modulation of these chemokines than observed in the animals with AIDS alone. Finally, the levels of expression of CCL23, XCL1, and CX3CL1 did not change after SIV infection (Table 2). In contrast to the CCR5 ligands CCL3 and CCL4, which increased in expression after SIV infection, the levels of CCL5 did not change.

The localization of cells expressing a subset of these chemokine mRNAs was examined in lung tissue sections by using ISH. We focused mainly on chemokines that were increased during the course of infection, reasoning that they would be the most likely to contribute to inflammation and tissue pathology. Expression of the three CXCR3 ligands (CXCLs 9 to 11) was minimal in uninfected and acutely infected macaques, but was up-regulated in nearly all macaques with AIDS, especially in those animals with AIDS and PCP (Table 3). In animals developing AIDS without concomitant PCP, CXCR3 ligand $\mathrm{mRNA}^{+}$cells were rare and generally scattered throughout the interstitium, whereas in animals with AIDS and PCP, cells expressing these chemokine mRNAs were localized to larger foci both within alveolar aggregates and interstitium (Figure 1A). Cells expressing CCL2 to CCL5 mRNAs were localized in similar patterns, with high expression in macaques developing AIDS and PCP (Table 3). To identify the cellular sources of chemokines in lung tissues, we combined $\mathrm{IHC}$ for cellular markers with ISH for chemokine mRNAs. The mRNAs encoding CXCL9 to 11 and CCL2 to 4 were all produced predominantly by $\mathrm{CD}^{+} 8^{+}$macrophages (Figure $1, \mathrm{~F}$ and $\mathrm{G}$ ) with only a small proportion produced by lymphocytes or lung epithelial cells (not shown). When CXCR3 ligands were expressed in compact foci, $\mathrm{CXCR}^{+}$cells were intensely localized to these areas (Figure $1 \mathrm{H}$ ).

As an indirect measure of the effects of these chemokines on the local environments, we next measured the levels of expression of 18 chemokine receptor mRNAs in macaque lung tissues by using real-time RT-PCR, and found that only 12 were detectable by this approach with these primer/probe sets. Among the undetectable chemokine receptors it was surprising that CXCR1 and CXCR2 were not detected even in the tissues from animals with AIDS and PCP, although we cannot rule out that the human primers and probes used for real-time RT-PCR hybridized to regions with species-specific nucleotide substitutions. CXCR3, CCR1, and CCR5 were the only chemokine receptors that increased in expression (1.8to 3.9-fold) during SIV infection (Table 2), consistent with the up-regulation of their cognate chemokines. Lung tissue SIV RNA levels were positively correlated with CXCR3 $(r=0.548)$ and CCR5 $(r=0.598)$ mRNA levels (Table 4). Immunostaining for CXCR3 was generally consistent with the mRNA analyses and revealed that $\mathrm{CXCR}^{+}$cells were increased in SIV-infected lung tissue sections, including in large but dispersed inflammatory aggregates in lungs from animals with AIDS and PCP (eg, Figure 1B). The positive correlations between CXCR3 and CCR5 expression, and that of their ligands (Table 4), suggest that these chemokines

Table 3. In situ Hybridization Signals for Cellular and Pathogen RNAs in Cynomolgus Macaque Lung Tissues during SIV Infection

\begin{tabular}{|c|c|c|c|c|c|c|c|c|c|c|c|c|c|c|c|c|}
\hline & \multicolumn{6}{|c|}{ Uninfected } & \multicolumn{2}{|c|}{ Acute } & \multicolumn{2}{|c|}{$\begin{array}{l}\text { Clinical } \\
\text { latency }\end{array}$} & \multicolumn{6}{|c|}{ AIDS } \\
\hline & 6202 & 7102 & 13402 & 13502 & 5702 & 7402 & 6002 & 7902 & 13002 & 13102 & 5802 & 5902 & 7002 & 12402 & 12602 & 12802 \\
\hline CXCL9/Mig & $+1-$ & - & - & $+1-$ & - & $+1-$ & $+1-$ & $+1-$ & + & + & ++ & $+1-$ & - & +++ & +++ & + \\
\hline CXCL10/IP-10 & $+1-$ & - & - & - & - & - & $+1-$ & $+1-$ & - & $+1-$ & + & - & - & +++ & +++ & +++ \\
\hline CXCL11/I-TAC & $+1-$ & $+1-$ & $+1-$ & - & - & $+1-$ & ++ & + & + & + & + & - & $+1-$ & +++ & +++ & + \\
\hline IFN- $\gamma$ & - & - & - & - & - & - & $+1-$ & $+1-$ & $+1-$ & $+1-$ & + & $+1-$ & $+1-$ & +++ & ++ & ++ \\
\hline CCL2/MCP-1 & $+1-$ & + & $+1-$ & $+1-$ & $+/-$ & + & ++ & + & + & + & ++ & $+1-$ & $+1-$ & +++ & +++ & +++ \\
\hline CCL3/MIP-1 $\alpha$ & $+1-$ & + & $+1-$ & $+1-$ & $+1-$ & $+1-$ & +++ & ++ & + & $+1-$ & + & $+1-$ & $+1-$ & +++ & +++ & +++ \\
\hline CCL4/MIP-1 $\beta$ & $+1-$ & + & + & $+1-$ & $+/-$ & $+1-$ & + & ++ & + & + & ++ & + & + & +++ & +++ & +++ \\
\hline CCL5/RANTES & + & + & + & - & - & ++ & + & ++ & ++ & ++ & +++ & ++ & ++ & +++ & +++ & +++ \\
\hline SIV & - & - & - & - & - & - & + & + & $+1-$ & + & $+1-$ & $+1-$ & $+1-$ & +++ & ++ & ++ \\
\hline P. carinii & - & - & - & - & - & - & - & - & - & - & - & - & - & +++ & +++ & +++ \\
\hline
\end{tabular}

ISH was performed with antisense and control sense ${ }^{35}$ S-labeled riboprobes specific for SIV, $P$. carinii, IFN- $\gamma$, and chemokines RNAs.

- denotes no signal detected; +/- denotes rare mRNA + cells in entire tissue section; + denotes 1 to 5 mRNA + cells per $200 \times$ field; ++ denotes 6 to 10 mRNA + cells per 200 $\times$ field; +++ denotes $>10$ mRNA + cells per $200 \times$ field. 


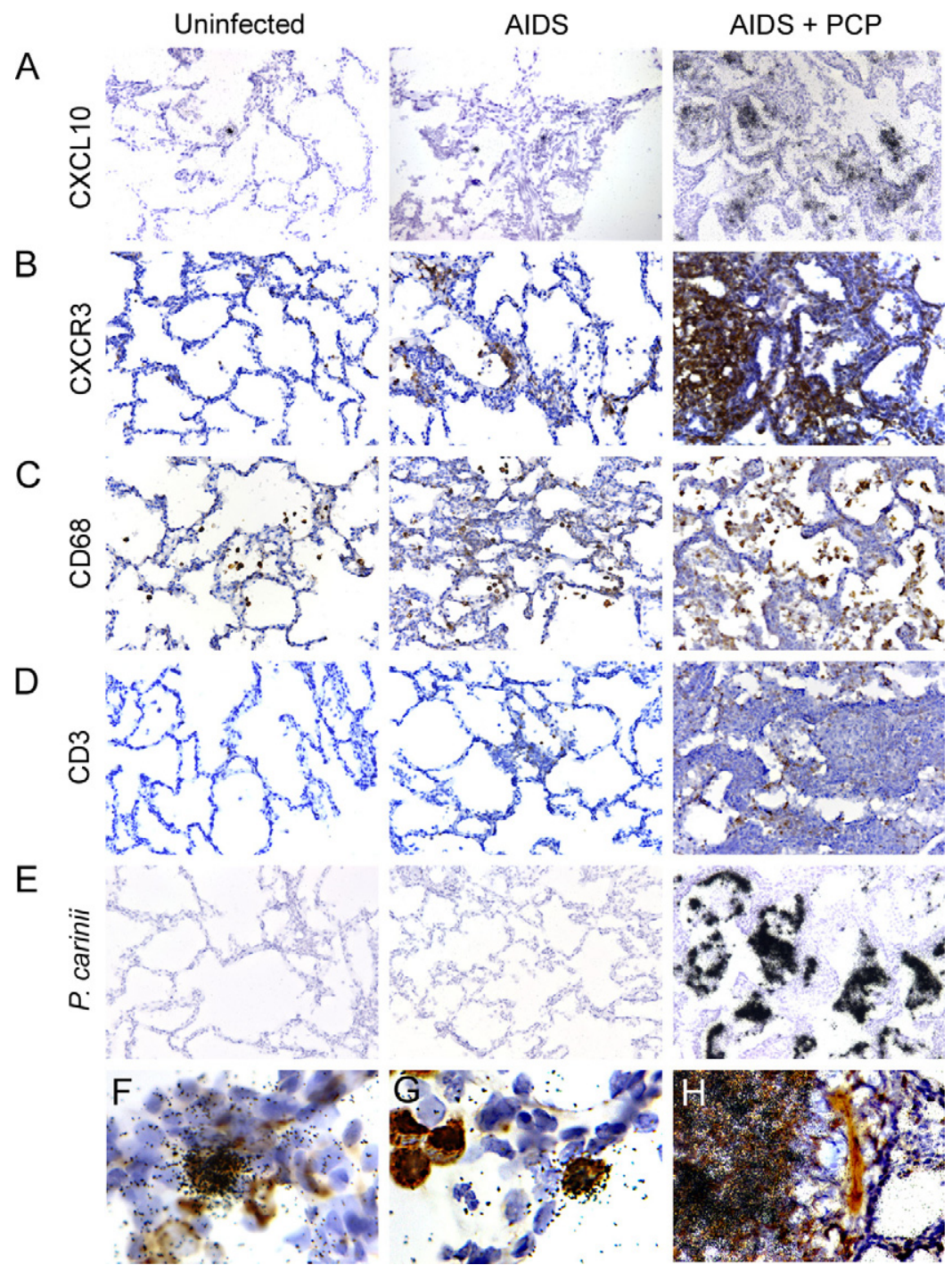

Figure 1. Localization of CXCL10 mRNA, cell-type markers, and $P$. carinii rRNA in lung tissue sections from SIVinfected and uninfected macaques. ISH was performed by using the indicated ${ }^{35} \mathrm{~S}$-labeled cRNA probes. IHC was performed by using anti-CD68 (macrophages), antiCD3 (T lymphocytes), or anti-CD183/CXCR3 (CXCR3 ${ }^{+}$ cells) monoclonal antibodies. Cells staining positively for the indicated antigens are visualized as brown. Original magnification, $\times 200$ (A-E). Simultaneous in situ hybridization and immunohistochemical detection of chemokine mRNAs and cell type markers in macaque lung tissues. The deposition of brown precipitate during IHC identified cells that expressed CD68 (macrophages) and CD183/CXCR3 (CXCR3 ${ }^{+}$cells), whereas focal collections of black silver grains identify cells expressing the specific mRNA. (F) CXCL9/CD68; (G) CCL2/CD68; (H) CXCL9/ CXCR3; Original magnification: $\times 400(\mathbf{F}$ and $\mathbf{G}) ; \times 100$ (H) and then zoom in

were indeed contributing to the recruitment of cells bearing these chemokine receptors.

\section{TLR Expression Patterns Reveal Up-Regulation of Toll-Like Receptor 3 during SIV Infection}

TLRs are a family of conserved pattern recognition receptors that are involved in innate immunity and the interface between the innate and adaptive responses. ${ }^{27}$ Given that the lungs are a large interface with the environment and constantly exposed to a wide spectrum of microorganisms, and that TLR engagement could contribute to altered chemokine expression profiles, we used real-time RT-PCR to measure the relative levels of expression of TLR1-10 mRNAs in macaque lung tissues. All TLR mRNAs were detectable except for TLR1 and TLR7, and the levels of expression of these mRNAs relative to an endogenous control gene in descending order were as follows: TLR4 (0.52) > TLR9 (0.02) > TLR6 (0.01) > TLR5 $(0.01)>\operatorname{TLR} 3\left(1.8 \times 10^{-3}\right)>\operatorname{TLR} 2\left(1.8 \times 10^{-5}\right)>\operatorname{TLR} 8$ $\left(1.9 \times 10^{-6}\right)>\operatorname{TLR} 10\left(5.0 \times 10^{-7}\right)$. Only TLR3 mRNA expression increased (5.1-fold) during SIV infection (Ta- ble 2). These findings indicate that the lungs are poised to immediately respond to a large set of pathogen-associated molecular patterns and that TLR3, which recognizes double-stranded RNA intermediates of viral replication and RNAs associated with apoptotic bodies 28,29 is increased in expression and could contribute to the induction of inflammatory chemokines.

\section{Up-Regulation of IFN- $\gamma$ and IL-10 mRNA Expression in SIV Infected Macaque Lung Tissues}

Given that TLR stimulation often leads to increased IFN expression, TLRs are abundantly expressed in lung tissues, and CXCR3 ligands are IFN-inducible, we measured the expression levels of type I and II IFNs in macaque lung tissues. The local levels of IFN- $\alpha$ and IFN- $\beta$ mRNAs did not change in expression during SIV infection, whereas IFN- $\gamma$ mRNA levels increased (Table 2). There were significant differences between the entire group of SIV-infected animals and the group developing 
Table 4. Correlations between Relative mRNA Expression Levels in Cynomolgus Macaque Lung Tissues during SIV Infection

\begin{tabular}{|c|c|c|}
\hline Gene-specific mRNA & $\begin{array}{c}\text { Comparison } \\
\text { gene specific } \\
\text { mRNA }\end{array}$ & $\begin{array}{l}\text { Pearson's } \\
\text { correlation } \\
\text { coefficient } \\
(P \text { value })^{*}\end{array}$ \\
\hline \multirow[t]{9}{*}{ CXCL9/Mig } & SIV & $0.546(0.029)$ \\
\hline & IFN- $\gamma$ & $0.508(0.044)$ \\
\hline & CXCL10/IP-10 & $0.813(<0.001)$ \\
\hline & CXCL11/I-TAC & $0.698(0.003)$ \\
\hline & CXCR3 & $0.549(0.028)$ \\
\hline & CCL2/MCP-1 & $0.544(0.029)$ \\
\hline & CCL4/MIP-1 $\beta$ & $0.575(0.020)$ \\
\hline & CCL5/RANTES & $0.689(0.003)$ \\
\hline & CCL18/PARC & $0.610(0.012)$ \\
\hline \multirow[t]{5}{*}{ CXCL10/IP-10 } & SIV & $0.791(<0.001)$ \\
\hline & $\mathrm{IFN} \gamma$ & $0.733(0.001)$ \\
\hline & CXCL9/Mig & $0.813(<0.001)$ \\
\hline & CXCL11/I-TAC & $0.897(<0.001)$ \\
\hline & CXCR3 & $0.764(0.001)$ \\
\hline \multirow{3}{*}{ CXCL11/I-TAC } & CXCL9/Mig & $0.698(0.003)$ \\
\hline & CXCL10/IP-10 & $0.897(<0.001)$ \\
\hline & CCL2/MCP-1 & $0.548(0.028)$ \\
\hline \multirow[t]{6}{*}{ CXCR3 } & CCL18/PARC & $0.532(0.034)$ \\
\hline & CXCL9/Mig & $0.549(0.028)$ \\
\hline & CXCL10/IP-10 & $0.764(0.001)$ \\
\hline & IFN- $\gamma$ & $0.809(<0.001)$ \\
\hline & CCR5 & $0.590(0.016)$ \\
\hline & SIV & $0.538(0.028)$ \\
\hline \multirow[t]{4}{*}{ IFN- $\gamma$} & CXCL9/Mig & $0.508(0.044)$ \\
\hline & CXCL10/IP-10 & $0.733(0.001)$ \\
\hline & CXCR3 & $0.809(<0.001)$ \\
\hline & SIV & $0.616(0.011)$ \\
\hline CCL4/MIP-1 $\beta$ & CCR5 & $0.600(0.014)$ \\
\hline \multirow[t]{2}{*}{ CCL5/RANTES } & CCR5 & $0.614(0.007)$ \\
\hline & CCR1 & $0.527(0.036)$ \\
\hline \multirow{4}{*}{ CCR5 } & CCL4/MIP-1 $\beta$ & $0.600(0.014)$ \\
\hline & CCL5/RANTES & $0.614(0.007)$ \\
\hline & CXCR3 & $0.590(0.016)$ \\
\hline & SIV & $0.598(0.014)$ \\
\hline \multirow[t]{7}{*}{ IL-10 } & CCL20/MIP-3 $\alpha$ & $0.728(0.001)$ \\
\hline & CCL3/MIP-1 $\alpha$ & $0.828(<0.001)$ \\
\hline & CCL4/MIP-1 $\beta$ & $0.554(0.026)$ \\
\hline & CCL19/MIP-3 $\beta$ & $0.670(0.005)$ \\
\hline & SIV & $0.657(0.006)$ \\
\hline & CCL21/6Ckine & $-0.539(0.031)$ \\
\hline & CXCL12/SDF- $1 \alpha$ & $-0.517(0.040)$ \\
\hline \multirow[t]{11}{*}{ SIV } & IFN- $\gamma$ & $0.616(0.011)$ \\
\hline & IL-10 & $0.657(0.006)$ \\
\hline & CXCL9/Mig & $0.546(0.029)$ \\
\hline & CXCL10/IP-10 & $0.791(<0.001)$ \\
\hline & CXCL11/I-TAC & $0.831(<0.001)$ \\
\hline & CCL19/MIP-3 $\beta$ & $0.601(0.014)$ \\
\hline & CCL3/MIP- $1 \alpha$ & $0.536(0.032)$ \\
\hline & CXCR3 & $0.548(0.028)$ \\
\hline & CCR5 & $0.598(0.014)$ \\
\hline & CCL21/6Ckine & $-0.561(0.024)$ \\
\hline & CCL25/TECK & $-0.535(0.033)$ \\
\hline
\end{tabular}

*Shown are all Pearson's correlations for which $P<0.05$.

AIDS, both relative to uninfected controls $(P=0.004$ and $P=0.011$, respectively; Table 2). IFN- $\gamma$ mRNA levels were correlated positively with CXCL9/Mig $(r=0.508)$ and CXCL10/IP-10 $(r=0.733)$ mRNA levels (Table 4 and Figure 2). Using ISH we found that IFN- $\gamma$ mRNA ${ }^{+}$cells were absent or rare in lung tissues of uninfected and acutely infected animals, and animals developing AIDS
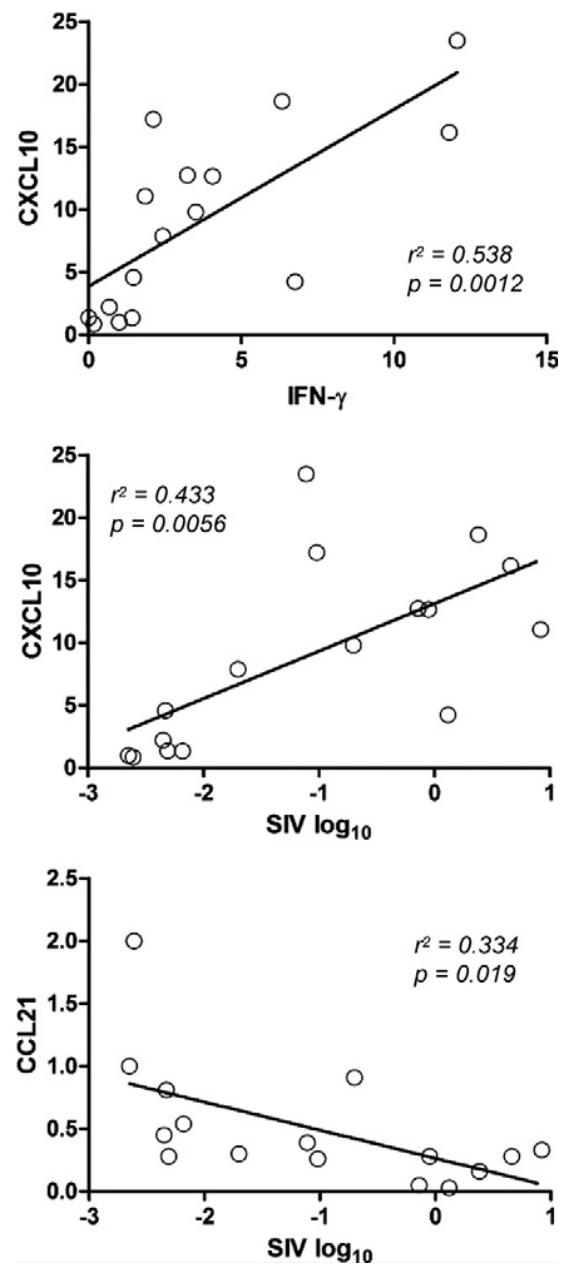

Figure 2. Example correlation analyses of lung tissue RNA measurements Pearson's correlation analyses were performed in Graphpad Prism for the indicated RNA measurements made by real-time RT-PCR. The $r^{2}$ and $P$ values for linear correlations are shown.

without concomitant PCP. In contrast, IFN- $\gamma$ mRNA ${ }^{+}$cells were noticeably increased among inflammatory infiltrates in lung tissues of animals with AIDS and PCP (Table 3), and the patterns and levels of IFN- $\gamma$ mRNA expression were concordant with local CXCR3 ligand expression (Table 3).

IL-10 is an anti-inflammatory cytokine, and can suppress Th1 lymphocyte responses, IFN- $\gamma$ expression, activation of macrophages, and release of chemotactic factors from neutrophils. ${ }^{30}$ We found that the SIV-infected animals, especially animals developing AIDS, had higher IL-10 mRNA expression in lung tissues compared with uninfected animals (4.4-fold and 5.6-fold, respectively; Table 2). There were significant differences between the entire group of SIV-infected animals and the group-developing AIDS, both relative to the uninfected controls $(P=0.031$ and 0.047 , respectively; Table 2$)$.

\section{Inflammatory Cell Infiltration in Lung Tissues During SIV Infection}

Alteration of chemokine networks is likely to change the immune cell composition of SIV-infected lung tissues. To 
A

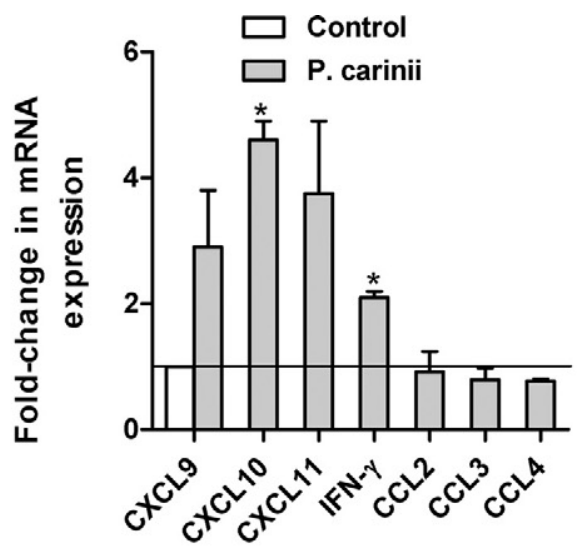

B

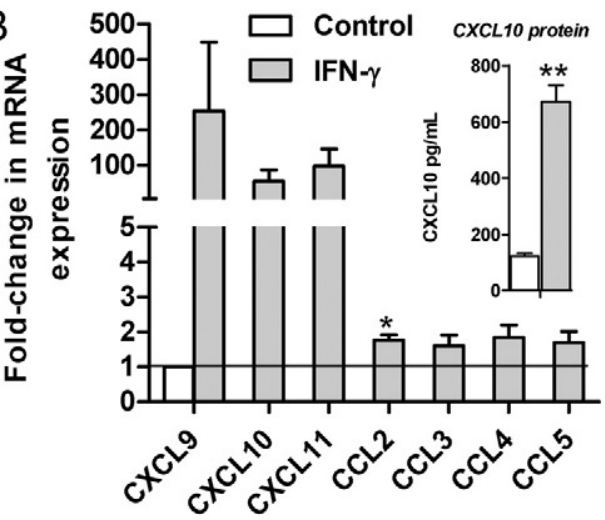

C
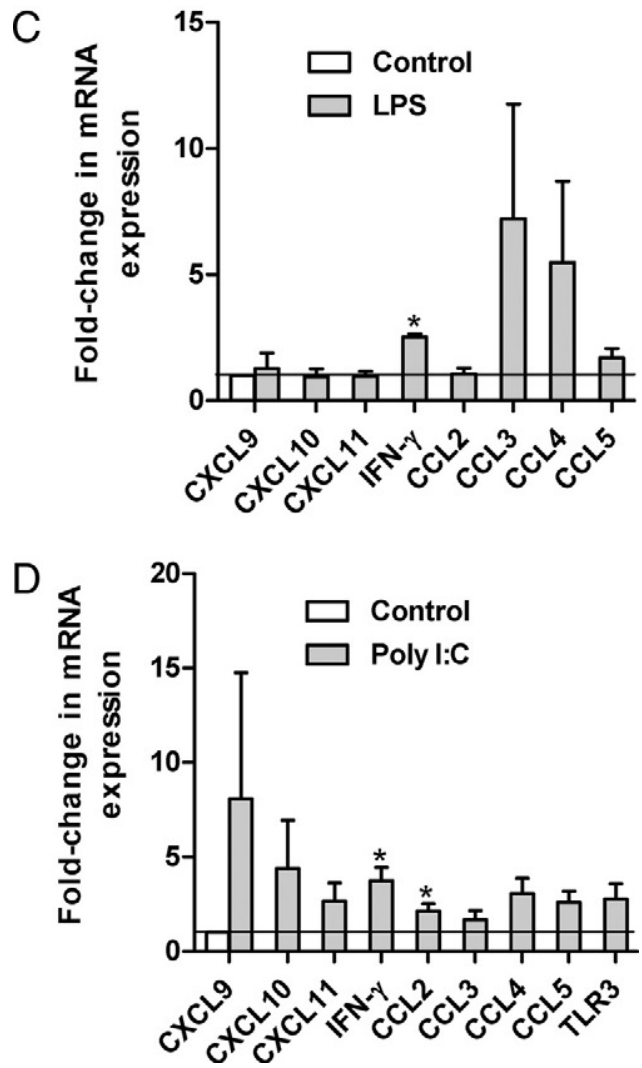

examine this, we performed IHC for multiple immune cell populations, and found that the numbers of macrophages and T-lymphocytes dramatically increased in animals with AIDS and PCP (Figure 1, C and D) both in alveolar and interstitial microcompartments. In contrast, B-lymphocytes were rare in lung tissues and only slightly increased during development of AIDS (data not shown). There was a paucity of CD209/DC-SIGN ${ }^{+}$cells (data not shown) in the lung parenchyma throughout the entire course of disease, with most CD209/DC-SIGN ${ }^{+}$cells localized in the submucosa of conducting airways (data not shown), which was consistent with DC-SIGN expression in rhesus macaque lung tissues. ${ }^{31}$

\section{Local SIV and P. carinii Level were Positively Correlated with IFN- $\gamma, \mathrm{CXCR} 3$, and CCR5 Ligand Expression in Lung Tissues}

To further clarify the relations between SIV and chemokine expression, we used real-time RT-PCR and ISH to determine local SIV viral loads and expression patterns in macaque lung tissues and found that the expression of SIV RNA in the lung was not abundant compared with lymphoid tissues (Tables 1 and 3 ). The numbers of cells expressing SIV mRNA were higher in lung tissues of the animals with acute SIV infection or AIDS with PCP involvement, compared with animals in clinical latency or developing AIDS without PCP. Correlation analyses revealed that SIV RNA levels were positively correlated with IFN- $\gamma$, CXCL9-11, CCL3, and CCL19 mRNA levels, but negatively correlated with CCL21 and CCL25 (Table 4 and Figure 2). These data indicated that there were associations between local SIV RNA levels in lung tissues and changes in expression of IFN- $\gamma$ and CXCR3 and CCR5 ligands.

To determine whether increased chemokine expression was associated with the local burdens of $P$. carinii, we performed ISH and RT-PCR for $P$. carinii rRNA. These analyses revealed that within the limits of sensitivity of these assays, $P$. carinii rRNA was not measurably present in uninfected or acutely infected macaques, or in three of the macaques with AIDS. However, the remaining three macaques that developed AIDS and clearly had pneu-

Figure 3. Induction of IFN- $\gamma$ and CXCR3, CCR1, and CCR5 ligands in lung cells by $P$. carinii, IFN- $\gamma$, LPS, and Poly(I:C). Lung single cell suspensions from uninfected macaques were cultured and exposed to P. carinii, IFN- $\gamma$, LPS, or Poly(I:C) for 24 hours, and the relative mRNA levels of the indicated genes were measured by using real-time RT-PCR in cultured lung cells of SIV uninfected macaques, and the concentrations of CXCL10 protein in the supernatant of cultured lung cells from the same animals were measured by ELISA after exposure to $P$. carinii, IFN- $\gamma$, LPS, or Poly(I:C). In $\mathbf{A}$ is shown the induction of IFN- $\gamma$, CXCR3 ligand, and CCR 5 ligand mRNAs with $P$. carinii at 24 hours poststimulation. In $\mathbf{B}$ is shown the induction of IFN- $\gamma$, CXCR 3 ligand, CCR1 ligand, and CCR5 ligand mRNAs and CXC10 protein (B inset) with IFN- $\gamma$ at 24 hours poststimulation. In $\mathbf{C}$ is shown the induction of IFN- $\gamma$, CXCR3 ligand, CCR1 ligand, and CCR5 ligand mRNAs with LPS at 24 hours poststimulation. In $\mathbf{D}$ is shown the induction of CXCR3 ligand, CCR1 ligand, and CCR5 ligand as well as IFN- $\gamma$ and TLR3 mRNAs with Poly(I:C) at 24 hours poststimulation. The calibrator was the lung cell culture without stimulation at 0 hours. These are combined data from two to three animals and two to three independent experiments, and the mean + SEM are shown. ${ }^{*} P<0.05$; ${ }^{* *} P<0.01$ compared with control lung cells at the same time point (paired $t$-test for $\mathbf{A}$-D; two sample $t$-test for inset in $\mathbf{B}$ ). 
monia had abundant $P$. carinii rRNA in lung tissues (Table 3 and Figure $1 \mathrm{E}$ ). Interestingly, we found that in vitro, $P$. carinii induced the expression of IFN- $\gamma$ and $\mathrm{CXCR} 3$ ligand mRNAs in lung cells (Figure 3A), but did not significantly induce the expression of CCL3-5 mRNAs. These findings indicate that $P$. carinii likely has a direct role in the induction of inflammatory chemokines in macaque lung tissues.

\section{IFN- $\gamma$, LPS, and Poly(l:C) Induced Lung Cells to Express CXCR3 and CCR5 Ligands in Vitro}

To understand better the relations between local pathogens, and chemokine and cytokine expression levels in lung tissues, we used IFN- $\gamma$, LPS, and Poly $(I: C)$ to stimulate cultures of lung cells obtained from uninfected macaques and measured mRNAs encoding chemokines and chemokine receptors. Although comprised of multiple cell types, these cell populations all were derived from uninfected macaques and anticipated to model the sum of complex pathogen-cell, cell-cell, and cytokinecell interactions that might occur within lung tissues. The TLR ligands LPS and Poly(I:C) were used to mimic exposure to bacterial and viral pathogen-associated molecular patterns, respectively. Treatment of lung cells with IFN- $\gamma$ potently induced the expression of CXCL9-11 mRNAs and moderately induced CCL2 mRNA expression, but did not significantly induce the expression of CCL3-5 mRNAs (Figure 3B). ELISA analysis of the culture supernatants for CXCL10 protein levels indicated that the secreted protein levels and mRNA levels for this chemokine were generally concordant (Figure 3B inset). LPS induced the expression of CCL3-5 and IFN- $\gamma$ mRNAs, but did not induce the expression of CXCL9-11 and CCL2 mRNAs (Figure 3C), and Poly (I:C) induced the expression of IFN- $\gamma$, CCL2, CXCR3 ligand, and CCR5 ligand mRNAs as well as TLR3 mRNAs (Figure 3D). These results indicate that host immune modulators (IFN- $\gamma$ ), as well as pathogen components (LPS and dsRNA), induce lung cells to express different overlapping sets of inflammatory chemokines, including those we determined to be up-regulated in lung tissues during SIV infection.

\section{Discussion}

Chemokines play central roles in the response to HIV-1 infection ${ }^{32}$ both as competing ligands for viral coreceptors on cell surfaces and as inflammatory signals that shape local immune environments. In previous studies we and others have found that SIV infection alters the levels of IFN- $\gamma$-inducible CXCR3 ligands ${ }^{33}$ and lymphoid homing chemokines ${ }^{34}$ in lymph nodes. In this study we focused on lung mucosal tissues in cynomolgus macaques and found that inflammatory modulators (eg, IFN- $\gamma$, CXCR3 ligands, and CCR5 ligands), were also up-regulated during SIV infection, particularly in animals with clear $P$. carinii coinfection. In addition, IFN- $\gamma$, CXCL9, and CXCL10 levels were positively correlated with each other, and SIV viral loads in lung tissues were positively correlated with most of the up-regulated chemokine and cytokine mRNAs. Providing insight into potential mediators of these changes, IFN- $\gamma$, LPS, Poly(I:C), and $P$. carinii were found to induce macaque lung cells ex vivo to express CXCR3 and CCR5 ligands. Taken together, these studies provide a comprehensive definition of the chemokine networks available to modulate cellular recruitment to lung tissues during SIV infection, and implicate both cytokines (IFN- $\gamma$ ) and pathogens (SIV and $P$. carinii) as responsible for the increased expression of pro-inflammatory chemokines in lung tissues.

The CXCR3 ligands, CXCL9, CXCL10, and CXCL11, are consistently up-regulated in lymphoid ${ }^{14}$ and pulmonary (shown here) tissues after SIV infection. CXCR3 is expressed on activated T-lymphocytes, particularly type- $1 \mathrm{~T}$ cells, ${ }^{35}$ activated natural killer cells, ${ }^{36}$ and plasmacytoid DCs. ${ }^{37}$ Inflammatory reactions comprised of increased CXCR3 ligand expression are therefore complex and involve both innate and adaptive immune responses in the lungs. These chemokines induce migration of $\mathrm{CXCR}^{+}{ }^{+} \mathrm{T}$ cells from the blood through the blood vascular endothelium into the pulmonary interstitium, and then into the alveolar spaces. These T cells (Th1) release IFN- $\gamma$ that results in additional induction of CXCL9 to 11 by alveolar macrophages and epithelial cells, establishing an inflammatory positive feedback loop. In the context of active HIV-1 replication, CXCL9 to 11 expression could simultaneously recruit $\mathrm{T}$-lymphocytes that combat viral replication but also provide new substrates for ongoing viral replication.

Chemokines CCL3 to 5 are the natural ligands for CCR5, a major coreceptor of HIV-1 and SIV. These chemokines are produced at sites of inflammation, where they are involved in the recruitment of T-lymphocytes and macrophages, but the net effect of $\beta$-chemokine levels in SIV infections is unclear. A number of studies have shown that the $\beta$-chemokines can block HIV-1 and SIV replication. ${ }^{5,38}$ However, some studies have shown that high $\beta$-chemokine levels correlate with disease progression during SIV and HIV-1 infection. ${ }^{15,39} \mathrm{LaFranco}-S c h e u c h$ et $\mathrm{al}^{40}$ reported that high lymph node vRNA levels also correlated with increased levels of CCL3/MIP- $1 \alpha$ and CCL4/MIP- $1 \beta$. Our findings that increased $\beta$-chemokine expression levels were associated with higher lung tissue viral RNA levels indicate that the local expression of these chemokines was not sufficient to inhibit SIV replication in lung tissues. CCR5 ligands might contribute to the immunopathogenesis of HIV-1/SIV infections in much the same way as CXCR3 ligands likely do, in that as viral replication and other events result in increased chemokine production, there is a resultant increase in homing of target cells (T-lymphocytes and macrophages) into lung tissues that enhance the inflammatory response and support further viral replication.

CCL18, also known as pulmonary activation and regulated chemokine (PARC), is produced by macrophages, DCs, and alveolar epithelial cells and is thought to be involved in naïve T cell recruitment. ${ }^{41}$ Additionally, CCL18 has been described as a marker of alternative activation of macrophages. ${ }^{42}$ Our results here have shown that the 
expression of CCL18 mRNAs was increased in the lung tissues from SIV-infected animals. Increased CCL18 expression in SIV-infected lungs might mediate the recruitment of subsets of $T$ lymphocytes and the activation of macrophages during the development of inflammation. In addition, we found down-regulation of CCL21, CCL25, and CXCL12 mRNA expression in SIV-infected lung tissues compared with controls. It has been reported that CCL21, CCL25, and CXCL12 are involved in protection from apoptosis. ${ }^{43-45}$ Therefore, the decrease of CCL21, CCL25, and CXCL12 in SIV-infected lungs could contribute to increased apoptosis of host cells, which in turn could lead to increased stimulation of TLR3 by RNAladen apoptotic bodies. ${ }^{46}$

$\mathrm{IL}-10$ is an anti-inflammatory cytokine and can suppress Th1 lymphocyte responses and activation of macrophages. SIVmac251-infected macaques with AIDS have higher expression of IL-10 mRNA in peripheral lymphoid tissues compared with controls, ${ }^{47}$ and individuals with HIV-1 infection have higher circulating IL-10 levels than controls, with the highest levels among patients with AIDS. ${ }^{48,49}$ In a murine PCP model, gene therapy with viral IL-10 can reduce tissue inflammation without altering pathogen clearance. ${ }^{50}$ In this study, we found that macaques with SIV infection, especially animals with AIDS, had higher IL-10 mRNA expression in lung tissues compared with uninfected macaques. The increased IL-10 levels could reflect a response to increased levels of immune activation, in an attempt to reduce the inflammatory response and subsequent damage to the lungs during SIV and P. carinii infections.

TLRs are a family of conserved pathogen recognition receptors, which function by recognition of and response to specific conserved motifs possessed by microorganisms. TLRs are expressed on many cell types including $T$ and B lymphocytes, DCs, macrophages, and epithelial cells, and are involved in innate and adaptive immunity. We have previously found that TLR3, which recognizes dsRNA viral replication intermediates, plays a potential role in SIV-associated inflammation in lymphoid tissues as well as in inhibition of SIV replication. ${ }^{10}$ In this study, we found that many TLRs are expressed in lung tissues, but that only TLR3 mRNA expression increased in lung tissues during SIV infection (Table 2). Induction of TLR3 expression in lung tissues might result in part from local SIV replication because Poly (I:C) can induce lung cells to express TLR3 in vitro (Figure 3D). As in lymphoid tissues, ${ }^{10}$ increased TLR3 levels could lead to higher local expression of inflammatory chemokines. The expression of most TLRs in lung tissues indicates that the lungs are poised to rapidly respond to a large set of pathogenassociated molecular patterns and therefore can contribute to the altered chemokine expression profiles we have defined here in lung tissues.

The causes leading to up-regulation of inflammatory chemokines are likely to be multifactorial. Pathogens (SIV and P. carinii) and host immune modulators (IFN- $\gamma$ ) could contribute to the up-regulation of these chemokine genes. Levels of CCL2, CCL3, CCL4, XCL1, and MIP-2 mRNAs were significantly elevated in the lungs of immu- nologically reconstituted $P$. carinii-infected severe combined immunodeficiency mice. ${ }^{51}$ We found that CXCR3 and CCR5 ligand expression was higher in the animals with AIDS and PCP than in animals with AIDS but without $\mathrm{PCP}$, and that in vitro $P$. carinii can induce IFN- $\gamma$ and CXCR3 ligand mRNA expression. Consistent with our findings here, CCL2 and CXCL10 in rhesus macaques infected with simian/human immunodeficiency virus is strongly associated with the development of pneumonia. ${ }^{52}$ Similarly, CXCL9 and CXCL10 were found by us through microarray analyses to be up-regulated in rhesus macaque lung tissues. ${ }^{13}$ Taken altogether, our data strongly suggest that $P$. carinii is involved in induction of these chemokines. These increased chemokines would recruit more inflammatory cells to infected sites and thus contribute to damaging inflammation in the infected lung tissue.

One limitation of our study is that both RNA analyses of homogenized tissues and the histological analyses of tissue sections are complicated by the architecture of lung tissue. Normal lung tissue is predominantly airspace, and on interstitial and/or alveolar infiltration there can be increased numbers of multiple cell types per pulmonary cavity volume, but on a per cell basis might or might not appear to be changing. This is a challenge that all lung tissue studies face, even with use of "region of interest" analyses of lung tissue sections using quantitative image analysis, and underscores the need for the simultaneous application of multiple approaches to the study of lung tissue inflammation.

Our findings have important implications for the treatment and prevention of HIV-associated pulmonary complications. In patients with AIDS who have P. carinii pneumonia, effective antimicrobial therapy is available, but excessive inflammation is still an important problem. For instance, some patients with severe PCP develop respiratory failure after initiation of antimicrobial therapy, ${ }^{53}$ and the pathogenesis of respiratory failure could involve tissue injury mediated through an excessive host inflammatory response to the pathogen destroyed by antibiotic agents. It has also been reported that there is paradoxical worsening of PCP in patients started on highly active antiretroviral therapy. ${ }^{54}$ Clinical and experimental studies have shown that inflammatory injury is a major cause of morbidity and mortality associated with PCP, potentially due to a more robust immune response to pulmonary microorganisms. We found that immune dysregulation triggered by SIV and $P$. carinii, and increased expression of IFN- $\gamma$, and CXCR3 and CCR5 ligands are associated with these inflammatory responses. This would imply that control or interruption of the inflammatory response might improve the outcome of PCP. Immunotherapies modulating these immune mediators might reduce potentially damaging inflammation in lung tissues. Blocking interaction of chemokines and their receptors should be useful therapeutically in HIV-1 or SIV infection with opportunistic infections, in which particular receptors and their ligands might be responsible for the excessive recruitment of inflammatory cells. 


\section{Acknowledgments}

We thank Dawn McClemens-McBride (University of Pittsburgh Primate Facility for Infectious Disease Research) for assistance with project coordination and animal care, Dr. Premi Rajakumar for performing the plasma viral load determinations, Dr. Karen Norris for providing a $P$. carinii rRNA clone, Dr. Francois Villinger for the IFN- $\gamma$ cDNA, and Dr. Terry Wright for purified $P$. carinii.

\section{References}

1. Ashley EA, Johnson MA, Lipman MC: Human immunodeficiency virus and respiratory infection. Curr Opin Pulm Med 2000, 6:240-245

2. Allen SJ, Crown SE, Handel TM: Chemokine: receptor structure, interactions, and antagonism. Annu Rev Immunol 2007, 25:787-820

3. Yang D, Chen Q, Hoover DM, Staley P, Tucker KD, Lubkowski J, Oppenheim JJ: Many chemokines including CCL20/MIP-3alpha display antimicrobial activity. J Leukoc Biol 2003, 74:448-455

4. Lusso P: HIV and chemokines: implications for therapy and vaccine. Vaccine 2002, 20:1964-1967

5. Cocchi F, DeVico AL, Garzino-Demo A, Arya SK, Gallo RC, Lusso P: Identification of RANTES, MIP-1 alpha, and MIP-1 beta as the major HIV-suppressive factors produced by CD8+ T cells. Science 1995 270:1811-1815

6. Mack M, Luckow B, Nelson PJ, Cihak J, Simmons G, Clapham PR, Signoret N, Marsh M, Stangassinger M, Borlat F, Wells TN, Schlondorff D, Proudfoot AE: Aminooxypentane-RANTES induces CCR5 internalization but inhibits recycling: a novel inhibitory mechanism of HIV infectivity. J Exp Med 1998, 187:1215-1224

7. Glass WG, Rosenberg HF, Murphy PM: Chemokine regulation of inflammation during acute viral infection. Curr Opin Allergy Clin Immunol 2003, 3:467-473

8. Murphey-Corb M, Martin LN, Rangan SR, Baskin GB, Gormus BJ, Wolf RH, Andes WA, West M, Montelaro RC: Isolation of an HTLV-IIIrelated retrovirus from macaques with simian AIDS and its possible origin in asymptomatic mangabeys. Nature 1986, 321:435-437

9. Fallert BA, Reinhart TA: Improved detection of simian immunodeficiency virus RNA by in situ hybridization in fixed tissue sections: combined effects of temperatures for tissue fixation and probe hybridization. J Virol Methods 2002, 99:23-32

10. Sanghavi SK, Reinhart TA: Increased expression of TLR3 in lymph nodes during simian immunodeficiency virus infection: implications for inflammation and immunodeficiency. J Immunol 2005, 175:5314-5323

11. Fuller DH, Rajakumar PA, Wilson LA, Trichel AM, Fuller JT, Shipley T, Wu MS, Weis K, Rinaldo CR, Haynes JR, Murphey-Corb M: Induction of mucosal protection against primary, heterologous simian immunodeficiency virus by a DNA vaccine. J Virol 2002, 76:3309-3317

12. Durand-Joly I, Wakefield AE, Palmer RJ, Denis CM, Creusy C, Fleurisse L, Ricard I, Gut JP, Dei-Cas E: Ultrastructural and molecular characterization of Pneumocystis carinii isolated from a rhesus monkey (Macaca mulatta). Med Mycol 2000, 38:61-72

13. Schaefer TM, Fuller CL, Basu S, Fallert BA, Poveda SL, Sanghavi SK, Choi YK, Kirschner DE, Feingold E, Reinhart TA: Increased expression of interferon-inducible genes in macaque lung tissues during simian immunodeficiency virus infection. Microbes Infect 2006, 8: $1839-1850$

14. Qin S, Sui Y, Soloff AC, Junecko BA, Kirschner DE, Murphey-Corb MA, Watkins SC, Tarwater PM, Pease JE, Barratt-Boyes SM, Reinhart TA: Chemokine and cytokine mediated loss of regulatory $T$ cells in lymph nodes during pathogenic simian immunodeficiency virus infection. J Immunol 2008, 180:5530-5536

15. Hofmann-Lehmann R, Williams AL, Swenerton RK, Li PL, Rasmussen RA, Chenine AL, McClure HM, Ruprecht RM: Quantitation of simian cytokine and beta-chemokine mRNAs, using real-time reverse transcriptase-polymerase chain reaction: variations in expression during chronic primate lentivirus infection. AIDS Res Hum Retroviruses 2002, 18:627-639

16. Godfrey TE, Kim SH, Chavira M, Ruff DW, Warren RS, Gray JW, Jensen $\mathrm{RH}$ : Quantitative mRNA expression analysis from formalinfixed, paraffin-embedded tissues using $5^{\prime}$ nuclease quantitative re- verse transcription-polymerase chain reaction. J Mol Diagn 2000, 2:84-91

17. Vissers JL, Hartgers FC, Lindhout E, Teunissen MB, Figdor CG, Adema GJ: Quantitative analysis of chemokine expression by dendritic cell subsets in vitro and in vivo. J Leukoc Biol 2001, 69:785-793

18. Katou $F$, Ohtani $H$, Nakayama $T$, Nagura $H$, Yoshie $O$, Motegi $K$ : Differential expression of CCL19 by DC-Lamp+ mature dendritic cells in human lymph node versus chronically inflamed skin. J Pathol 2003, 199:98-106

19. Hieshima K, Imai T, Baba M, Shoudai K, Ishizuka K, Nakagawa T, Tsuruta J, Takeya M, Sakaki Y, Takatsuki K, Miura R, Opdenakker G, Van DJ, Yoshie O, Nomiyama H: A novel human CC chemokine PARC that is most homologous to macrophage-inflammatory protein-1 alpha/LD78 alpha and chemotactic for $\mathrm{T}$ lymphocytes, but not for monocytes. J Immunol 1997, 159:1140-1149

20. Pegu A, Flynn JL, Reinhart TA: Afferent and efferent interfaces of lymph nodes are distinguished by expression of lymphatic endothelial markers and chemokines. Lymphat Res Biol 2007, 5:91-103

21. Kim CH, Lim HW, Kim JR, Rott L, Hillsamer P, Butcher EC: Unique gene expression program of human germinal center $T$ helper cells. Blood 2004, 104:1952-1960

22. Vicari AP, Figueroa DJ, Hedrick JA, Foster JS, Singh KP, Menon S, Copeland NG, Gilbert DJ, Jenkins NA, Bacon KB, Zlotnik A: TECK: a novel CC chemokine specifically expressed by thymic dendritic cells and potentially involved in T cell development. Immunity 1997, 7:291-301

23. Wurbel MA, Philippe JM, Nguyen C, Victorero G, Freeman T, Wooding P, Miazek A, Mattei MG, Malissen M, Jordan BR, Malissen B, Carrier A, Naquet $P$ : The chemokine TECK is expressed by thymic and intestinal epithelial cells and attracts double- and single-positive thymocytes expressing the TECK receptor CCR9. Eur J Immunol 2000, 30:262-271

24. Gunn MD, Tangemann K, Tam C, Cyster JG, Rosen SD, Williams LT: A chemokine expressed in lymphoid high endothelial venules promotes the adhesion and chemotaxis of naive $T$ lymphocytes. Proc Natl Acad Sci USA 1998, 95:258-263

25. Kuroshima S, Sawa Y, Yamaoka Y, Notani K, Yoshida S, Inoue N: Expression of cys-cys chemokine ligand 21 on human gingival lymphatic vessels. Tissue Cell 2004, 36:121-127

26. Qin S, Sui Y, Murphey-Corb MA, Reinhart, TA: Association between decreased CXCL12 and CCL25 expression and increased apoptosis in lymphoid tissues of cynomolgus macaques during SIV infection. J Med Primatol 2008, 37(Suppl 2):46-54

27. Akira S, Takeda K, Kaisho T: Toll-like receptors: critical proteins linking innate and acquired immunity. Nat Immunol 2001, 2:675-680

28. Alexopoulou L, Holt AC, Medzhitov R, Flavell RA: Recognition of double-stranded RNA and activation of NF-kappaB by Toll-like receptor 3. Nature 2001, 413:732-738

29. Kariko K, Ni H, Capodici J, Lamphier M, Weissman D: mRNA is an endogenous ligand for Toll-like receptor 3. J Biol Chem 2004, 279:12542-12550

30. Moore KW, de Waal MR, Coffman RL, O'Garra A: Interleukin-10 and the interleukin-10 receptor. Annu Rev Immunol 2001, 19:683-765

31. Fuller CL, Choi YK, Fallert BA, Capuano S, III, Rajakumar P, MurpheyCorb M, Reinhart TA: Restricted SIV replication in rhesus macaque lung tissues during the acute phase of infection. Am J Pathol 2002, 161:969-978

32. Garzino-Demo A, DeVico AL, Conant KE, Gallo RC: The role of chemokines in human immunodeficiency virus infection. Immunol Rev 2000, 177:79-87

33. Reinhart TA, Fallert BA, Pfeifer ME, Sanghavi S, Capuano S, III, Rajakumar P, Murphey-Corb M, Day R, Fuller CL, Schaefer TM: Increased expression of the inflammatory chemokine CXC chemokine ligand 9/monokine induced by interferon-gamma in lymphoid tissues of rhesus macaques during simian immunodeficiency virus infection and acquired immunodeficiency syndrome. Blood 2002, 99:3119-3128

34. Choi YK, Fallert BA, Murphey-Corb MA, Reinhart TA: Simian immunodeficiency virus dramatically alters expression of homeostatic chemokines and dendritic cell markers during infection in vivo. Blood 2003, 101:1684-1691

35. Bonecchi R, Bianchi G, Bordignon PP, D'Ambrosio D, Lang R, Borsatti A, Sozzani S, Allavena P, Gray PA, Mantovani A, Sinigaglia F: Differential expression of chemokine receptors and chemotactic responsiveness of type 1 T helper cells (Th1s) and Th2s. J Exp Med 1998, 187:129-134 
36. Maghazachi AA: G protein-coupled receptors in natural killer cells. J Leukoc Biol 2003, 74:16-24

37. Kohrgruber N, Groger M, Meraner P, Kriehuber E, Petzelbauer $\mathrm{P}$, Brandt S, Stingl G, Rot A, Maurer D: Plasmacytoid dendritic cell recruitment by immobilized CXCR3 ligands. J Immunol 2004, 173:6592-6602

38. Gauduin MC, Glickman RL, Means R, Johnson RP: Inhibition of simian immunodeficiency virus (SIV) replication by CD8(+) T lymphocytes from macaques immunized with live attenuated SIV. J Virol 1998, 72:6315-6324

39. Jennes W, Sawadogo S, Koblavi-Deme S, Vuylsteke B, Maurice C, Roels TH, Chorba T, Nkengasong JN, Kestens L: Positive association between beta-chemokine-producing T cells and HIV type 1 viral load in HIV-infected subjects in Abidjan. Cote d'Ivoire AIDS Res Hum Retroviruses 2002, 18:171-177

40. LaFranco-Scheuch L, Abel K, Makori N, Rothaeusler K, Miller CJ: High beta-chemokine expression levels in lymphoid tissues of simian/ human immunodeficiency virus 89.6-vaccinated rhesus macaques are associated with uncontrolled replication of simian immunodeficiency virus challenge inoculum. J Virol 2004, 78:6399-6408

41. Adema GJ, Hartgers F, Verstraten R, de VE, Marland G, Menon S, Foster J, Xu Y, Nooyen P, McClanahan T, Bacon KB, Figdor CG: A dendritic-cell-derived C-C chemokine that preferentially attracts naive T cells. Nature 1997, 387:713-717

42. Kodelja V, Muller C, Politz O, Hakij N, Orfanos CE, Goerdt S: Alternative macrophage activation-associated CC-chemokine-1, a novel structural homologue of macrophage inflammatory protein-1 alpha with a Th2associated expression pattern. J Immunol 1998, 160:1411-1418

43. Banas B, Wornle M, Berger T, Nelson PJ, Cohen CD, Kretzler M, Pfirstinger J, Mack M, Lipp M, Grone HJ, Schlondorff D: Roles of SLC/CCL21 and CCR7 in human kidney for mesangial proliferation, migration, apoptosis, and tissue homeostasis. J Immunol 2002, 168:4301-4307

44. Qiuping Z, Jei X, Youxin J, Wei J, Chun L, Jin W, Qun W, Yan L, Chunsong $\mathrm{H}$, Mingzhen $Y$, Qingping $G$, Kejian Z, Zhimin S, Qun L, Junyan $\mathrm{L}$, Jinquan $\mathrm{T}$ : CC chemokine ligand 25 enhances resistance to apoptosis in CD4+ T cells from patients with T-cell lineage acute and chronic lymphocytic leukemia by means of livin activation. Cancer Res 2004, 64:7579-7587
45. Guo Y, Hangoc G, Bian H, Pelus LM, Broxmeyer HE: SDF-1/CXCL12 enhances survival and chemotaxis of murine embryonic stem cells and production of primitive and definitive hematopoietic progenitor cells. Stem Cells 2005, 23:1324-1332

46. Sadik CD, Bachmann M, Pfeilschifter J, Muhl H: Activation of interferon regulatory factor-3 via toll-like receptor 3 and immunomodulatory functions detected in A549 lung epithelial cells exposed to misplaced U1-snRNA. Nucleic Acids Res 2009, 37:5041-5056

47. Orandle MS, Williams KC, MacLean AG, Westmoreland SV, Lackner AA: Macaques with rapid disease progression and simian immunodeficiency virus encephalitis have a unique cytokine profile in peripheral lymphoid tissues. J Virol 2001, 75:4448-4452

48. Stylianou E, Aukrust P, Kvale D, Muller F, Froland SS: IL-10 in HIV infection: increasing serum IL-10 levels with disease progressiondown-regulatory effect of potent anti-retroviral therapy. Clin Exp Immunol 1999, 116:115-120

49. Ameglio F, Cordiali FP, Solmone M, Bonifati C, Prignano G, Giglio A, Caprilli F, Gentili G, Capobianchi MR: Serum IL-10 levels in HIVpositive subjects: correlation with CDC stages. J Biol Regul Homeost Agents 1994, 8:48-52

50. Ruan S, Tate C, Lee JJ, Ritter T, Kolls JK, Shellito JE: Local delivery of the viral interleukin-10 gene suppresses tissue inflammation in murine Pneumocystis carinii infection. Infect Immun 2002, 70:6107-6113

51. Wright TW, Johnston CJ, Harmsen AG, Finkelstein JN: Chemokine gene expression during Pneumocystis carinii-driven pulmonary inflammation. Infect Immun 1999, 67:3452-3460

52. Sui Y, Li S, Pinson D, Adany I, Li Z, Villinger F, Narayan O, Buch S Simian human immunodeficiency virus-associated pneumonia correlates with increased expression of MCP-1, CXCL10, and viral RNA in the lungs of rhesus macaques. Am J Pathol 2005, 166:355-365

53. Maxfield RA, Sorkin IB, Fazzini EP, Rapoport DM, Stenson WM Goldring RM: Respiratory failure in patients with acquired immunodeficiency syndrome and Pneumocystis carinii pneumonia. Crit Care Med 1986, 14:443-449

54. Wislez M, Bergot E, Antoine M, Parrot A, Carette MF, Mayaud C, Cadranel $\mathrm{J}$ : Acute respiratory failure following HAART introduction in patients treated for Pneumocystis carinii pneumonia. Am J Respir Crit Care Med 2001, 164:847-851 